\title{
The Impact of Mergers and Acquisitions on the Performance of the Greek Banking Sector: An Event Study Approach
}

\author{
Panagiotis Liargovas (Corresponding author) \\ University of Peloponnese, School of Economics and Management, Department of Economics \\ Terma Karaiskaki Street (OAED Building), Tripolis, 22100, Greece \\ Tel: 30-271-023-0130, Fax: 30-271-023-0139 E-mail: liargova@uop.gr \\ Spyridon Repousis \\ University of Peloponnese, School of Economics and Management, Department of Economics \\ Terma Karaiskaki Street (OAED Building), Tripolis, 22100, Greece \\ Tel: 30-271-023-0128, Fax: 30-271-023-0139Ｅ-mail: spyrep@otenet.gr
}

Received: August 7, $2010 \quad$ Accepted: August 24, $2010 \quad$ doi:10.5539/ijef.v3n2p89

\begin{abstract}
This paper examines the impact of Greek mergers and acquisitions on the performance of the Greek Banking Sector during the period 1996-2009. With the use of event study methodology, we reject the "semi-strong form" of Efficient Market Hypothesis (EMH) of the Athens Stock Exchange. We find that ten days prior to the announcement of a merger and acquisition, shareholders receive considerable and significant positive cumulative average abnormal returns (CAARs). Also the results show that significant positive CAARs are gained upon the announcement of horizontal and diversifying bank deals. The overall results indicate that bank mergers and acquisitions have no impact and do not create wealth. We also examine operating performance of the Greek Banking Sector by estimating twenty financial ratios. Findings show that operating performance does not improve, following mergers and acquisitions. There are also controversial results when comparing merged to non-merged banks.
\end{abstract}

Keywords: Banks, M\&As, Event Study, Operating Performance, Greece

\section{Introduction}

The Greek financial system was deregulated in the mid -1980s. Before that, it was over-regulated, as a result of the extensive government intervention in credit allocation, since the early 1950s. After 1987, the Greek financial system started to change. Globalization, as well as the process of financial integration within the European Union, lead to modernization of the Greek financial system, with interest rate deregulation, liberalization of cross-border capital movement and abolition of direct credit controls.

The Greek banking industry has also undergone substantial changes due to the fact that Greece became a member of the European Union in 1981. Before 1981, the Greek Central Bank used to impose limitations on commercial banks' credit expansion and interest rate ceilings. Two state-owned banks, National Bank of Greece and Commercial Bank of Greece, dominated almost the whole Greek banking sector. The 1989 Second Banking Co-ordination Directive gave banks the opportunity to operate as universal banking institutions, extending their business into financial activities other than traditional ones, such as insurance and investment services. Cost cuts, restructuring, mergers and acquisitions, followed the Greek banking industry after 1992. Greek banks started to internationalize their activities while at the same time competition and profitability increased.

The process of globalization changed the Greek banking landscape and spurred the largest wave of mergers and acquisitions (M \& As) so far. In the period 1996-2008 a large number of mergers and acquisitions were completed. The growing and more complex competition increased in the Greek banking sector as a result of a more liberalized regulatory framework, the emergence of new financial intermediaries and new information technologies.

Currently, the Greek economy and the Greek banking sector are in a weak fiscal position. The European Union and the International Monetary Fund, acting as international lenders of last resort, announced the availability of huge funds. The European Central Bank enhanced credit support to Greece by accepting Greek state bonds as collateral regardless of credit rating from Rating Agencies such as Moody's, Fitch and Standard and Poor's. Also the International Monetary Fund, the European Commission and the European Central Bank, reached an agreement to stabilize the Greek economy and restore market confidence with the support of a $€ 110$ billion financing package in 
order to safeguard financial stability in the euro area. Among the key elements of the package is setting up a Financial Stability Fund of about $€ 10$ billion, funded by the financing package, to ensure a sound level of bank equity. In order to prevent possible future liquidity crisis, there is a need to improve liquidity buffer (safe assets) of Greek banking sector which means higher capital adequacy standards to limit liquidity risk and better risk management. A combination of mergers and acquisitions might be a possible solution to a future Greek banking sector crisis. Therefore, the detailed analysis of the impact of mergers and acquisitions on the performance of the Greek Banking Sector is of great importance.

The next section of the paper provides a theoretical and empirical discussion of mergers and acquisitions. Section 3 presents the data and the methodologies used. Finally, section 4 provides the empirical results, while section 5 offers some concluding remarks.

\section{Theoretical and empirical underpinnings}

The theoretical literature of mergers and acquisitions can be divided into three major categories. The first category includes synergy or efficiency, in which total value from the combined firms is greater than the sum of values of each firm. Increased value arises from increased efficiency (output or input) and increased market power. Hubris is the second category and it is the result of winner's curse, causing bidders to overpay while value is unchanged. The third category comprises those in which total value is decreased as a result of mistakes or managers who put their own preferences above firm's (principal-agent problem), "building empires" for self-interest opposed to the self-interest of the principal and the shareholders.

The empirical evidence concerning the evaluation of mergers and acquisitions is based on five different types of analysis namely, production functions, cost functions, use of accounting data, the efficient frontier approach and event studies (Matthews \& Thompson; 2005). The concept of efficiency measurement assumes that the production function of the fully efficient firm or firms is known. Since, this is not the case in practice, one has to estimate the production function. The production function is estimated from sample data applying either a non-parametric (mathematical programming) or a parametric (econometric) approach. The three main parametric techniques are the Stochastic Frontier Approach (SFA), the Distribution-Free Approach (DFA) and the Thick Frontier Approach (TFA). As for the definition of inputs and outputs of a banking firm, there is no consensus on the variables that best define bank output.

According to the production approach (Benson \& Smith, 1976), banks transform labor and capital inputs into two output groups of assets and liabilities. The number and type of transactions and documents are considered to be the best measure of bank output. But such specific data are generally unavailable and therefore, in practice, the number of deposit and loan accounts is usually employed as the measure of bank output.

A large number of researchers use the "intermediation approach" (e.g. Sealey \& Lindley, 1977) which treats banks as mediators transforming funds between depositors and investors. The main task of a bank is to channel funds from savers to investors. Within this framework, deposits are treated as inputs and loans as outputs. This approach is distinguished from the production approach by adding deposits to inputs with consideration of both operating cost and interest cost (Goddard et al., 2001).

Siems (1996) used the event methodology in the case of 24 US bank mega-mergers (deals exceeding $\$ 500 \mathrm{~m}$ ) in 1995. He showed that the shares of the target bank rose by $13.04 \%$ but those of the acquirer fell by $1.96 \%$ (both results were significant at the $1 \%$ level). There have been also a number of studies using accounting data. Vander Vennet (1996) examined European bank mergers over the period 1988-1993 and used both accounting data and the efficient approach. The accounting data consisted of a wide range of financial measures such as return on assets, return on equity and asset utilization. He concluded that domestic mergers between equal-sized partners significantly increased the efficiency of the merged banks.

Cornett \& Tehranian (1992), examined the post-acquisition of large bank mergers between1982 and 1987. They reported that the merged banks outperform the banking industry. Rezitis (2008), using a stochastic output function, found that the effects of mergers and acquisitions on technical efficiency and on total factor productivity growth of Greek banks are rather negative. Noulas (1997), examined productivity growth of Greek banking industry for 1991 and 1992, using the Malmquist productivity index and the Data Envelopment Analysis method (DEA) and found that, although productivity has increased for state and private banks, the sources of this growth are different.

Spathis, Kosmidou \& Doumpos (2002), using multicriteria methodology (M.H.DIS and UTADIS) investigated the endogenous factors of Greek banks from their financial statements over the period 1990-1999, identifying financial ratios that affect classification of banks according to their size. Evidence indicated that large banks are more efficient than small ones. Also using the Promethee method to evaluate the performance of commercial and 
cooperative banks in Greece, Kosmidou \& Zopounidis (2008), found that commercial banks tend to increase their accounts, to attract more customers and ameliorate their financial indices, thereby becoming more competitive and maximizing their profits. Halkos \& Salamouris (2004), applying a non-parametric technique (Data Envelopment Analysis) and exploring financial efficiency ratios for the period 1997-1999, found that the higher the size of total assets, the higher the efficiency of Greek commercial banks.

Event study methodology is based on Efficient Market Hypothesis (EMH) developed by Fama et al. (1969) and Fama (1970). According to this, a market is efficient if "prices fully reflect all available information". One important assumption is that capital markets are sufficiently efficient to react on events (new information) regarding expected future profits of affected corporations. Efficiency is classified as "weak form" when information set includes past prices, "semi - strong form" when information set includes all publicly available information and "strong form" when information set includes all publicly and privately available information. Event studies are mostly rested upon the analysis of the so-called "normal" and "abnormal" returns which are estimated on the basis of asset pricing model.

Kavussanos \& Dockery, (2001) showed that the Athens Stock Exchange is inefficient which means that past stock prices have some information of future moves of stock prices. The same evidence was showed by Siourounis (2002), using a GARCH model. Also the random walk hypothesis was rejected for the Greek stock market because of autocorrelation in returns (Smith \& Ryoo, 2003).

Mylonidis \& Kelnikola (2005), using event study approach and a 20 days event window before and after announcement date for the years 1999-2000 and the empirical methods of Dodd \& Warner (1983) and Houston \& Ryngaert (1994), showed that mergers create value on a net aggregate basis. Also by using operating performance methodology they found no evidence of performance gains resulting from bank mergers. Overall, it seems that the Greek banking sector over-reacts to the arrival of new information (the announcement of the merger), hence questioning the efficiency of the Efficient Market Hypothesis. The latter contradicts the findings of Stengos \& Panas (1992) who gave support for the "weak" and "semi-strong form" of efficiency, using data of selected stocks from the Greek banking sector. According to "weak form" efficiency, the relevant stale information is past prices and returns and it is impossible to earn superior risk-adjusted profits based on the knowledge of past prices and returns. According to "semi-strong form efficiency" investors cannot earn superior risk-adjusted returns using any publicly available information. As information becomes public, it is immediately incorporated into prices and an investor cannot gain by using this information to predict returns.

Athanasoglou \& Brissimis (2004), employed operating performance methodology on revenue, cost, profit and productivity ratios in the pre-merger and acquisition period 1994-1997 and post-merger and acquisition period 2000-2002. They showed that merger and acquisitions positively affect merged banks' profitability as well as cost efficiency. Also Athanasoglou \& Brissimis (2005) using event study methodology for merger and acquisitions in the Greek banking sector for the period 1998-1999, examined seven cases and showed that target banks achieved higher cumulative abnormal returns than bidder banks.

When volatility is examined and a GARCH model is employed, there is a strong evidence that the Athens Stock Exchange follows a pattern where last period's daily returns are correlated with today's returns and current volatility is positively related to past realizations (Siourounis, 2002). According to Millionis \& Papanagiotou (2008), the Athens Stock Exchange reveals high variability of the performance of the moving average trading rule. The trading rule was found to have predictive power in the Athens Stock Exchange and results indicated that the moving average trading rule can beat the market.

\section{Data and Methodology}

In our research, we use Event Study and Operating Performance Methodology. The basis of event study is to examine the returns derived from the stock prices of the relevant firms both before and after the announcement of a merger and acquisition. An abnormal return (residual) is defined as the actual return (determined using arithmetic percentages) less the return predicted by the firm's beta, given the market return. The residual or abnormal return represents the part of the return that is not predicted and is, therefore, an estimate of the change in firm value on a day, which is caused by the event (merger announcement). The predicted return represents the return that would be expected if no event took place. The firm's beta is measured over an estimation period of 100 days prior to event window and the actual return is measured over a period of 30 days before and after the announcement date (event window of 61 days and announcement date is designated as day 0 in event window) following Brown \& Warner (1980; 1985).

Event window represents possible leakages of information before merger is announced and possible stock price reactions after merger is announced and it finally captures all the effects on stock prices of the event. The merger 
announcement date, daily stock prices, daily General Index of Athens Stock Exchange, as well as information about the merger and acquisition and other financial information, was mainly collected from Daily Bulletin and Database of Athens Stock Exchange and press releases of financial daily press (newspaper Nafteboriki).

To calculate predicted return, the Market Model Method is used. It is the most widely used method in event study literature because the Market Model takes explicit account of the risk associated with the market and mean returns. It is estimated by running the following regression:

$R_{i t}=a_{i}+b_{i} R_{m t}+e_{i t}$

where:

$R_{m t}$ is the return on a market index, such as the General Index of the Athens Stock Exchange for day $\mathrm{t}$,

$\alpha_{\mathrm{i}}$ measures the mean return over the period not explained by the market,

$b_{i}$ (beta coefficient) measures the sensitivity of bank $i$ to the market and it is a measure of risk,

$\mathrm{e}_{\mathrm{it}}$ is a statistical error term, $\Sigma \mathrm{e}_{\mathrm{it}}=0$.

The predicted return for a bank stock for a day in the event period is the return given by the market model on that day using regression analysis (Ordinary Least Squares), that is:

$\widehat{R_{l t}}=\widehat{a_{l t}}+b_{i} \widehat{R_{m t}}+e_{i t}$

where now $\widehat{R_{m} t}$ is the return on the market index for the actual day in the event period.

We also perform parametric tests as proposed by Brown \& Warner $(1980 ; 1985)$ for Average Abnormal Returns (AARs) and Cumulative Average Abnormal Returns (CAARs). CAARs represent the average total effect of the event across all firms over a specified time interval.

We examine nine cases of mergers and acquisitions that were completed during 1996-2008 and use t-test and hypotheses:

$\mathrm{H}_{1}: \mathrm{AAR} \neq 0 \quad$ and $\mathrm{H}_{0}: \quad \mathrm{AAR}=0$

$\mathrm{H}_{1}: \mathrm{CAAR} \neq 0$ and $\mathrm{H}_{0}: \mathrm{CAAR}=0$

The $\mathrm{H}_{0}$ hypothesis tests if stocks that are affected by the event act will not experience Average Abnormal Returns or Cumulative Average Abnormal Returns and $\mathrm{H}_{1}$ hypothesis tests if stocks that are affected by the event act will experience negative or positive Average Abnormal Returns or Cumulative Average Abnormal Returns, where each abnormal security return is normalized by its estimation period standard deviation. Analytically:

$$
t_{A A R}=\frac{A A R_{t}}{S\left(A A R_{t}\right)}
$$

Then, standard deviation is estimated as

$$
S(A A R)_{s}=\sqrt{\sum_{t=1}^{T_{0}} \frac{\sum A A R_{t}^{2}}{T_{0}-1}}
$$

where $\mathrm{T}_{0}$ will be the number of days in the estimation period.

The t-test assumes that the individual abnormal returns are cross-sectionally independent and identically distributed.

Also we estimate, t-statistic for $\mathrm{CAAR}_{\mathrm{s}}$ by dividing $\mathrm{CAAR}_{\mathrm{s}}$ with standard deviation:

$t_{C A A R}=\frac{C A A R_{t}}{\sqrt{T * S\left(A A R_{t}\right)}}$

If statistic tests show that $\mathrm{t}$-statistic is higher or equal to a crucial price, then hypothesis $\mathrm{H}_{0}$ will be rejected which means that $\mathrm{AAR}_{\mathrm{s}}$ or $\mathrm{CAAR}_{\mathrm{s}}$ will be statistically significant.

It is also interesting to investigate whether mergers and acquisitions create wealth (positive net present value). This is addressed by estimating the combined return to targets and bidders. The combined return is the weighted average of the returns of the two parties in the merger, where the weights are the equity value of the particular target and bidder. It is estimated as following:

$\mathrm{CAR}_{\text {comb }}=\left(\mathrm{MV}_{\mathrm{B}} \times \mathrm{CAR}_{\mathrm{B}}+\mathrm{MV}_{\mathrm{T}} \times \mathrm{CAR}_{\mathrm{T}}\right) /\left(\mathrm{MV}_{\mathrm{B}}+\mathrm{MV}_{\mathrm{T}}\right)$

where:

$\mathrm{CAR}_{\text {comb }}$ is combined cumulative abnormal return of the two parties in the merger,

$\mathrm{MV}_{\mathrm{B}}$ and $\mathrm{MV}_{\mathrm{T}}$ is market value of bidder and target firm respectively, on day -31 (one day before event window or last day of estimation period of 100 days). 
$\mathrm{CAR}_{\mathrm{B}}$ and $\mathrm{CAR}_{\mathrm{T}}$ are cumulative abnormal returns of bidder and target firm respectively during event window.

The absolute gain - wealth or loss at time $\mathrm{t}\left(\Delta \mathrm{W}_{\mathrm{t}}\right)$, due to the abnormal return during the event period is defined by:

$\Delta \mathrm{W}_{\mathrm{t}}=\mathrm{CAR}_{\mathrm{t}} \times \mathrm{MKTVAL}_{0}$

where:

$\mathrm{CAR}_{\mathrm{t}}$ is cumulative abnormal return to date $t$ of event window for a firm.

MKTVAL $_{0}$ is market value of the firm at a date previous to the event window interval. The percent return times the market value of the firm is the total gains or loss.

Further, the standard error of the test statistic for the combined entity is followed according to suggestions of Houston \& Ryngaert (1994). The variance of each combined entity is given by the following equation:

$\operatorname{VAR}\left[T_{C A R}\left(T_{1}, T_{2}\right)\right]=\left(M_{B} / M_{B}+M V_{T}\right)^{2} \times C_{A R}+\left(M_{\mathrm{T}} / M_{B}+M V_{T}\right) 2 \times C A R_{T}+2 \times\left(M_{B} / M_{B}+M V_{T}\right) \times$ $\left(\mathrm{MV}_{\mathrm{T}} / \mathrm{MV}_{\mathrm{B}}+\mathrm{MV} \mathrm{V}_{\mathrm{T}}\right) \times \rho_{\mathrm{BT}} \times \sqrt{ } \operatorname{Var}\left(\mathrm{CAR}_{\mathrm{B}}\right) \times \operatorname{Var}\left(\mathrm{CAR}_{\mathrm{T}}\right)$,

where:

$M V_{B}$ and $\quad \mathrm{MV}_{\mathrm{T}}$ are market values of bidder and target firms respectively, 31 days before announcement date and $\rho_{\mathrm{BT}}$ is the correlation coefficient of abnormal returns (residuals) of bidder and target firms according to the Market Model during 100 days of estimation period (before event window).

In addition, we use operating performance methodology by following Pilloff (1996). The merger-related change in performance variable has been calculated as the difference between pre-merger adjusted performance for the consolidated bank involved in merger and post-merger performance for the same bank. Balance sheets, annual reports and financial statements were found on ICAP Database, Hellenic Bank Association, daily economic newspapers, banks' websites and banks' accounting departments.

Following Pilloff (1996), the performance is examined with the use of 20 financial-accounting ratios, such as:

\section{Profitability Indicators}

1. Return on Equity $(\mathrm{ROE})=$ Net Income before taxes/Total equity

2. Return on Assets $(\mathrm{ROA})=$ Net Income before taxes/Total assets

3. Return on Assets plus Off-Balance Sheet Items $=$ Net Income before taxes/Total assets Off-Balance Sheet Items

4. Net Profit Margin (NPM) $=$ Net Income before taxes/Total revenues

5. Net interest rate margin $(\mathrm{NIM})=$ Net revenues from interest/Total assets

\section{Productivity Indicators}

1. Total assets/Total employees

2. Net Income before taxes/Total employees

3. Total revenues/Total loans

4. $\%$ change in total assets per year

5. \% change in total assets plus off-balance sheet items per year

Off-balance sheet items refer to credits and other guarantees, which are not reported on the balance sheet. We include off-balance sheet items in an attempt to capture securitization, brokerage services and management of financial assets for customers who become increasingly important in Greek banks.

Operating Indicators

1. Total Operating Efficiency $=$ Operating expenses/Operating revenues

2. Total revenues/Personnel and management expenses

3. Total expenses/ Personnel and management expenses

4. Total expenses/Total assets

5. Total expenses from interest paid/Total assets

6. Total expenses (except interest paid)/Total assets

Liquidity Indicators

1. Total loans/Total deposits 


\section{Total loans/Total assets}

3. Cash plus reserves plus securities/Total assets

Solvency Ratio

\section{Total equity/Total assets}

We apply the operating performance model specified above to an unbalanced panel of Greek banks studied over the period, 1996-2004, including a total sample of 26 Greek commercial banks (11 banks were involved in mergers and acquisitions activities and 15 banks as non-mergerd). Greek co-operative banks and branches of foreign banks are excluded. We investigate whether merged banks are following a different pattern of efficiency change than non-merged banks. For this reason, a merged institution is treated as a different bank from the institution that existed before the merging process.

Our study includes information on six cases of mergers and acquisitions ( 5 banks were involved as acquirers and 6 banks as targets) that meet the following criteria, as stated by Pilloff (1996): a) merger was the primary transaction in which both the bidder and target were involved during the period from at least one year before the merger year to at least one year after it, with maximum two years before and after, b) during this period, no other merger was announced by either party, c) the regulator did not encourage or assist the acquisition. We limit the empirical analysis to the unconsolidated statements of commercial banks in order to reduce the possibility of introducing aggregation bias in the results. All currency variables are expressed in millions of Euros, in 1995 real terms and corrected for inflation (deflated by the Wholesale Price Index published by the National Statistical Service of Greece). A total of 19 (about 35.1 per cent) of the banks were observed during the 9 years.

The hypothesis tested is:

$\mathrm{H}_{1}: \Delta \mathrm{WR}_{\mathrm{x}} \neq 0 \quad$ and $\quad \mathrm{H}_{0}: \quad \Delta \mathrm{WR}_{\mathrm{x}}=0$

where $\Delta \mathrm{WR}_{\mathrm{x}}$ is the weighted relative difference in variable $\mathrm{x}$. The relative size according to total assets of bidders and targets, by using t-test or t-student is:

$\mathrm{t}\left(\Delta \mathrm{WR} \mathrm{R}_{\mathrm{x}}\right)=\frac{\Delta W R_{t}}{\frac{S\left(\Delta W R_{x}\right)}{\sqrt{N}}}$

where $\mathrm{S}\left(\Delta \mathrm{WR}_{\mathrm{x}}\right)$ is standard deviation of weighted relative difference in variable $\mathrm{x}$ and $\mathrm{N}$ is number of mergers and acquisitions.

Finally, the Herfindahl-Hirschman Index (HHI) and Concentration Ratio of five largest banks (CR-5) in total assets of the individual banks (and total assets plus off-balance sheet items), have been calculated for the period 1996 2004.

\section{Empirical Results}

\subsection{Event Study Methodology}

The Market Model is used and residuals are tested whether merger events provide positive or negative abnormal returns to the participants. It also provides a basis for examining the issue of whether or not value is enhanced by mergers. Table 1 reports Cumulative Average Abnormal Returns (CAARs) for nine merger deals, for bidder and target banks. We observe that prior to merger and acquisition announcement and especially ten days before [-10;0], the shareholders of the targets and bidders receive considerable and significant positive cumulative average abnormal returns (CAARs), statistically significant at 5\%. Bidders realize capital gain of around $6 \%$ and targets capital gain of around 9\%, hence questioning the "semi-strong form" Efficient Market Hypothesis (EMH) of the Athens Stock Exchange.

Our results are partially consistent with the results of Athanasoglou \& Brissimis (2005) who examined merger deals during 1998-1999 and found positive abnormal returns prior to merger announcement. But they contradict Stengos \& Panas (1992) who find support for "weak" and "semi-strong form EMH".

In order to examine whether a merger deal is value-enchancing or destroying, we analyzed combined entity following suggestions of Houston \& Ryngaert (1994), by weighting abnormal returns with market capitalizations at the end of estimation period (last day of estimation period before start of event window). We used, again a 30 days event window. In four out of nine merger deal cases, combined returns were positive but, not statistically significant. The results imply that Greek bank M \& As is not wealth creating projects for the shareholders of the combined entity (Note 1).

Although a great deal of attention has been focused abroad on the possibility of gains from horizontal bank mergers, there is no previous work in the case of Greece. To cover this gap, we conduct t-test to determine whether four 
horizontal mergers or five diversified bank mergers deals, result in gains. As shown in Table 2, bidder banks engaged in diversified merger deals do not violate Efficient Market Hypothesis because even when abnormal returns exist, they are not statistically significant. Findings also indicate that horizontal bank merger deals generate CAARs for bidder banks, statistically significant one day prior until thirty days after announcement date, significant at 5\% level and statistically significant at $10 \%$ ten days prior to announcement date. In Table 2 , target banks engaged in diversified merger deals generate CAARs, statistically significant at $10 \%$ for the periods $[0 ;-30]$ and $[0 ;+10]$. Also CAARs are statistically significant at $5 \%$ level for periods $[0 ;+1]$ and $[-1 ;+1]$. Findings also indicate that horizontal bank merger deals generate CAARs for target banks, statistically significant at the $5 \%$ level in periods $[0 ;+1]$, $[0$; $+30],[0 ;+10]$ and $[-1 ;+1]$ and statistically significant at the $10 \%$ level in periods $[-30 ;+1],[0 ;-1]$.

To better understand the impact of mergers and acquisitions, we also measured whether the method of payment affects the wealth gains borne by bidder and target shareholders. For the three merger deals where method of payment was cash offer, the positive CAARs for bidder banks was $15.379 \%$, especially high, ten days before announcement, significant at 5\% level, which may reflect information leakage. For the three merger deals where method of payment was cash offer, the positive and negative CAARs for target banks were not statistically significant at $10 \%$ or $5 \%$ level. For the five merger deals where method of payment was stock offer, CAARs for bidder banks were not statistically significant at $5 \%$ level. Statistically significant at $10 \%$ level were only the negative CAARs for the period $[+20 ;+30]$. Finally, for the five merger deals where method of payment was stock offer, CAARs for target banks were statistically significant at $10 \%$ only for the period $[-20 ;-10]$ and statistically significant at $5 \%$ level for periods $[-30 ;+1],[0 ;+1],[0 ;+30],[0 ;-30],[-10 ; 0],[0 ;+10],[-1 ;+1],[0 ;-1]$ (Note 2 ).

\subsection{Operating Performance Methodology}

In this section, we measure the effects of mergers on performance, comparing pre- and post-merger performance of merged banks and performance of non-merged banks.

We first calculate the deflated Herfindahl-Hirschman Index (HHI) and Concentration Ratio of the five largest banks (CR-5) in total assets of the individual banks and total assets plus off-balance sheet items. As shown in Table 3, HHI, calculated by deflated total assets, increased during the years 1998, 2000 and 2002 but although there was merging activity, Greek banking industry is moderate and not highly concentrated. According to HHI, calculated by deflated total assets plus off balance sheet items, Greek banking industry is moderate and not highly concentrated, with the exemption of 2002 where the index moved above 1800 (high concentration).

Concentration Ratios of the five largest banks (CR-5) in total assets of the individual banks and total assets plus off-balance sheet items, were calculated for the period 1996 - 2004. It is shown that the Greek banking industry is moderately concentrated, where many and new banks have low market shares. More specifically, the average CR-5 in the case of deflated total assets was $76.9 \%$ and in the case of deflated total assets plus off balance sheet items, $78.6 \%$ respectively. Our findings are similar to those in a previous study by the European Central Bank (December 2000, p.17-19), according to which, the Greek banking industry was moderately concentrated during the 1995-1999 period.

Using Operating Performance Methodology, we calculated all financial ratios with weighted average pre-merger performance (according to weighted total assets of each bank in merger deal) and also weighted average difference (post merger performance minus weighted average pre-merger performance). The five profitability ratios (Table 4), show ability of a bank to generate profits generally from assets or equity. Our results indicate negative difference on average ratios, which means that banks are deteriorating after merger deal, but the decrease is not statistically significant.

As regards productivity ratios (Table 5), "net Income before taxes/Total employees" and "percentage change in total assets per year", indicate negative difference on average ratios, which means that they are deteriorating after merger deal but the decrease is not statistically significant. Two productivity ratios, "total revenues/total loans" and "percentage change in total assets plus off-balance sheet items per year", show negative difference which means that they are deteriorating after a merger deal, statistically significant at 10\% level. Only "Total Assets/Total Employees" is improving after a merger deal, statistically significant at $5 \%$ and $10 \%$ levels.

Operating ratios indicate possible reductions in operating efficiency and operating expenses. Findings show that five out of six operating ratios (Table 6) improve after merger deal (statistically significant at $5 \%$ and $10 \%$ levels). Only "Total expenses/ Personnel and management expenses" deteriorates (the ratio increases) after merger deal (statistically significant at $5 \%$ and $10 \%$ levels).

Liquidity ratios illustrate how a bank can meet its liabilities from acid assets, exposure at loans and share of loans to total assets. Results from two out three liquidity ratios (Table 7) deteriorate after merger deal, but they are not statistically significant. Only "cash plus reserves plus securities/Total assets" deteriorates after merger deal, and it is statistically significant. 
Finally, solvency ratio or capital adequacy ratio, illustrate banks' viability in the long run and indicate the source of funds (capital from shareholders, profits etc) that support operation (Table 8). "Total equity/total assets" of merged banks is lower from that of non-merged banks. Also the ratio deteriorates after merger deal but it is not statistically significant at $5 \%$ and $10 \%$.

\section{Conclusions}

The purpose of this paper was to examine the impact of mergers and acquisitions on the performance of Greek banking sector over the period 1996-2008, by using two approaches; event study methodology and operating performance. The results from event study methodology, using a 30-day event window indicate that stock prices show significant positive cumulative average abnormal returns (CAARs) before the announcement for a period of ten days (for targets and bidders banks). Moreover, cash deals create more significant positive CAARs for bidder shareholders than do stock deals, ten days before announcement. Also the results show that significant positive CAARs are gained upon the announcement of horizontal and diversifying bank deals for target's shareholders. The overall results (the weighted average of gains to the bidder and target bank), indicate that bank mergers and acquisitions have no impact and do not create wealth. The empirical results also indicate significant implications for rejection of the "semi-strong form" of Efficient Market Hypothesis (EMH) of the Athens Stock Exchange, possibly reflecting leakage of information. By measuring twenty financial ratios, we found that the Greek banking industry is moderate and not highly concentrated (many banks with low market shares). Operating performance does not improve following mergers and acquisitions while there are controversial results when comparing merged banks with the group of non-merging banks.

Overall, our results suggest the need to create an institutional mechanism to reduce possible leakages of information before a merger or an acquisition takes place. A possible solution might be the imposition of a lump-sum tax on mergers and acquisitions around the announcement date. The revenue from this tax could be used by the Financial Stability Fund to safeguard the stability of the financial and banking system.

Before we conclude, we must bear in mind all the limitations of relying on operating performance, because operating performance measures are subject to measurement problems (e.g. use of different accounting rules), they are vulnerable to manipulation and discretionary choice of accounting rules, and the appropriate time lag in measuring performance improvement is not clear. In addition, it is important to note that the Efficient Market Hypothesis, which the event study methodology depends upon, has received a lot of criticism. Therefore, future research should focus on alternative methods when evaluating mergers and acquisitions such as the stochastic frontier approach.

\section{References}

Athanasoglou, P. \& Brissimis, S. (2004). The impact of mergers and acquisitions on the efficiency of banks in Greece, Bank of Greece Economic Bulletin, 22, 7-34 (in Greek).

Athanasoglou, P., \& Brissimis, S. (2005). The impact of announcements of mergers and acquisitions on returns of Greek banks' stocks, Bank of Greece Economic Bulletin, 24, 29-48 (in Greek).

Benston, G., \& Smith, C. (1976). A Transactions Cost Approach to the Theory of Financial Intermediation, The Journal of Finance, 31, 215-231.

Brown, S., \& Warner, J. (1980). Measuring security price performance, Journal of Financial Economics, 8, 205-258, doi:10.1016/0304-405X(80)90002-1, http://dx.doi.org/10.1016/0304-405X(80)90002-1.

Brown, S., \& Warner, J. (1985). Using daily stock returns: The case of event studies, Journal of Financial Economics, 14, 3-31, doi:10.1016/0304-405X(85)90042-X, http://dx.doi.org/10.1016/0304-405X(85)90042-X

Cornett, M., \& Tehranian, H. (1992). Changes in corporate performance associated with bank acquisitions, Journal of Financial Economics, 31, 211-234, doi:10.1016/0304-405X(83)90018-1, http://dx.doi.org/10.1016/0304-405X(83)90018-1

Dodd, P., and Warner, J. (1983). On corporate governance: a study of proxy contests, Journal of Financial Economics, $11,401-438$.

European Central Bank, (December 2000). Mergers and Acquisitions involving the EU Banking Industry - Facts and implications.

Fama, E., Fisher, L., Jensen, M., \& Roll, R. (1969). The adjustment of stock prices to new information, International Economic Review, 10, 1-27.

Fama, E. (1970). Efficient capital markets: a review of theory and empirical work. Journal of Finance, 25 (2), 383-417. Goddard, J., Molyneux, P., \& Wlson, J. (2001). European Banking. England: John Wiley \& Sons. 
Halkos, G., \& Salamouris, D. (2004). Efficiency measurement of the Greek commercial banks with the use of financial ratios: a data envelopment analysis approach. Management Accounting Research, 15, 201-224, doi:10.1016/j.mar.2004.02.001, http://dx.doi.org/10.1016/j.mar.2004.02.001

Hondroyiannis, G., Lolos, S., \& Papapetrou, E. (1999). Assessing competitive conditions in the Greek banking system. Journal of International Financial Markets, Institutions and Money, 9, 377-391, doi:10.1016/S1042-4431(99)00017-7, http://dx.doi.org/10.1016/S1042-4431(99)00017-7

Houston, J., \& Ryngaert, M., (1994). The overall gains from large bank mergers, Journal of Banking and Finance, 18, 1155-1176, doi:10.1016/0378-4266(94)00065-4, http://dx.doi.org/ 10.1016/0378-4266(94)00065-4

Kavussanos, M., \& Dockery, E. (2001). A multivariate test for stock market efficiency: the case of ASE, Applied Financial Economics, 11, 573-579, doi: 10.1080/09603100010013006, http://dx.doi.org/10.1080/09603100010013006

Kosmidou, K. \& Zopounidis, C. (2008). Measurement of bank performance in Greece. South Eastern Europe Journal of Economics, 1, 79-95.

Matthews, K. \& Thompson, J. (2005). The Economics of Banking. England : John Wiley \& Sons Ltd.

Milionis, A., \& Papanagiotou, E. (2008). A note on the use of moving average trading rules to test for weak form efficiency in capital markets, Working Paper No.91, Bank of Greece, October 2008.

Mylonidis, N., \& Kelnikola, I. (2005). Merging activity in the Greek Banking system: A financial accounting perspective, South Eastern Europe Journal of Economics, 1, 121-144.

Noulas, A. (1997). Productivity growth in the Hellenic banking industry: state versus private banks. Applied Financial Economics, 7, 223-228, doi: 10.1080/096031097333574, http://dx.doi.org/10.1080/096031097333574

Pilloff, S. (1996). Performance changes and shareholder weath creation associated with mergers of publicly traded banking institutions. Journal of Money, Credit and Banking, 28, 294-310.

Rezitis, A. (2008). Efficiency and productivity effects of bank mergers: Evidence from the Greek banking industry. Economic Modelling, 25, 236-254, doi:10.1016/j.econmod.2007.04.013, http://dx.doi.org/10.1016/j.econmod.2007.04.013

Sealey, C.W., and Lindley, J. (1977). Inputs, Outputs and a Theory of Production and Cost at Depository Financial Institutions. The Journal of Finance, 32, 1251-1266.

Siems, T. (1996). Bank mergers and shareholder wealth: Evidence from 1995's Megamerger Deals. Federal Reserve Bank of Dallas, Financial Industry Studies, August, 1-12.

Siourounis, G. (2002). Modelling volatility and testing for efficiency in emerging capital markets: the case of the Athens stock exchange. Applied Financial Economics, 12, 47-55, doi:10.1080/09603100110088003, http://dx.doi.org/10.1080/09603100110088003 .

Smith, G., \&Ryoo, H-J. (2003). Variance ratio tests of the random walk hypothesis for European emerging stock markets. The European Journal of Finance, 9, 290-300, doi:10.1080/1351847021000025777, http://dx.doi.org/10.1080/1351847021000025777

Spathis, Ch., Kosmidou, K., \& Doumpos, M. (2002). Assessing profitability factors in the Greek banking system: A multicriteria methodology. International Transactions in Operational Research, 9, 517-530 , doi: 10.1111/1475-3995.00371, http://dx.doi.org/10.1111/1475-3995.00371

Stengos, T. \& Panas, E. (1992). Testing the efficiency of the Athens Stock Exchange: some results from the Banking sector. Empirical Economics, 17, 239-252, doi:10.1007/BF01206285, http://dx.doi.org/10.1007/BF01206285.

Sudarsanam, S. (2003). Creating value from mergers and acquisitions: The Challenges, England: Financial Times Prentice Hall International UK Limited.

Vennet, R.V. (1996). The effect of mergers and acquisitions on the efficiency and profitability of EC credit institutions. Journal of Banking and Finance, 20, 1531-1558, doi:10.1016/S0378-4266(96)00014-3, http://dx.doi.org/10.1016/S0378-4266(96)00014-3

Notes

Note 1. Results are available upon request.

Note 2. Results are available upon request. 
Table 1. CAARs for bidder and target banks

\begin{tabular}{|l|l|l|l|l|}
\hline & \multicolumn{2}{|l|}{ Bidder banks } & Target banks & t-statistic \\
\hline & CAAR & t-statistic & CAAR & -0.68 \\
\hline$[-30 ;+30]$ & -0.06 & -1.12 & -0.03 & 2.95 \\
\hline$[-30 ;+1]$ & $0.11^{* *}$ & 2.85 & $0.10^{* *}$ & -7.16 \\
\hline$[0 ;+1]$ & $0.04^{* *}$ & 3.68 & -0.06 & -5.77 \\
\hline$[0 ;+30]$ & -0.13 & -3.53 & -0.20 & 4.37 \\
\hline$[0 ;-30]$ & $0.10^{* *}$ & 2.55 & $0.15^{* *}$ & 1.93 \\
\hline$[-30 ;-20]$ & 0.01 & 0.54 & $0.04^{*}$ & 1.06 \\
\hline$[-20 ;-10]$ & 0.03 & 1.36 & 0.02 & 4.55 \\
\hline$[-10 ; 0]$ & $0.06^{* *}$ & 2.79 & $0.09 * *$ & -9.58 \\
\hline$[0 ;+10]$ & -0.02 & -1.01 & -0.20 & 1.05 \\
\hline$[+10 ;+20]$ & -0.05 & -2.15 & 0.02 & -1.30 \\
\hline$[+20 ;+30]$ & -0.06 & -2.43 & -0.03 & -5.43 \\
\hline$[-1 ;+1]$ & $0.04 * *$ & 3.40 & -0.06 & -1.26 \\
\hline$[0 ;-1]$ & $0.03^{* *}$ & 2.79 & -0.01 & \\
\hline
\end{tabular}

** significant at $5 \%$

Table 2. CAARs for bidder $\&$ target banks in diversified and horizontal merger deals

\begin{tabular}{|c|c|c|c|c|c|c|c|c|}
\hline & \multicolumn{4}{|c|}{ Bidder banks } & \multicolumn{4}{|c|}{ Target banks } \\
\hline & \multicolumn{2}{|c|}{ Diversified merger deals } & \multicolumn{2}{|c|}{ Horizontal merger deals } & \multicolumn{2}{|c|}{ Diversified merger deals } & \multicolumn{2}{|c|}{ Horizontal merger deals } \\
\hline & $\underline{\text { CAAR }}$ & $\underline{\text { t-statistic }}$ & $\underline{\mathrm{CAAR}}$ & t-statistic & $\underline{\text { CAAR }}$ & $\underline{\text { t-statistic }}$ & $\underline{\mathrm{CAAR}}$ & $\underline{\text { t-statistic }}$ \\
\hline$[-30 ;+30]$ & 0.06 & 0.95 & -0.16 & -2.06 & 0.02 & 0.24 & -0.07 & -0.96 \\
\hline$[-30 ;+1]$ & 0.11 & 2.30 & 0.11 & 1.96 & 0.07 & 1.29 & $0.13^{*}$ & 2.41 \\
\hline$[0 ;+1]$ & 0.01 & 0.97 & $0.05^{* *}$ & 3.92 & $-0.05^{* *}$ & -3.86 & $-0.07 * *$ & -5.30 \\
\hline$[0 ;+30]$ & -0.04 & -0.75 & $-0.21 * *$ & -3.88 & -0.10 & -1.95 & $-0.28 * *$ & -5.15 \\
\hline$[0 ;-30]$ & 0.11 & 2.28 & 0.09 & 1.59 & $0.13^{*}$ & 2.59 & $0.17 * *$ & 3.06 \\
\hline$[-30 ;-20]$ & 0.03 & 1.09 & 0.00 & -0.09 & 0.05 & 1.58 & 0.03 & 1.02 \\
\hline$[-20 ;-10]$ & 0.06 & 2.12 & 0.01 & 0.22 & 0.05 & 1.76 & 0.00 & -0.12 \\
\hline$[-10 ; 0]$ & 0.03 & 1.14 & $0.09 *$ & 2.69 & 0.03 & 0.87 & $0.15 * *$ & 4.56 \\
\hline$[0 ;+10]$ & 0.02 & 0.76 & -0.06 & -1.79 & $-0.14 *$ & -4.42 & $-0.25 * *$ & -7.65 \\
\hline$[+10 ;+20]$ & 0.01 & 0.37 & $-0.10^{* *}$ & -2.94 & 0.03 & 1.04 & 0.01 & 0.42 \\
\hline$[+20 ;+30]$ & -0.06 & -2.00 & -0.05 & -1.64 & 0.01 & 0.32 & -0.06 & -1.73 \\
\hline$[-1 ;+1]$ & 0.02 & 1.47 & $0.06^{* *}$ & 3.23 & $-0.05^{* *}$ & -3.34 & $-0.06^{* *}$ & -3.71 \\
\hline$[0 ;-1]$ & 0.02 & 1.58 & $0.03 *$ & 2.39 & 0.01 & 0.94 & $-0.03 *$ & -2.15 \\
\hline
\end{tabular}

$*$ significant at $10 \%, * *$ significant at $5 \%$

Table 3. Herfindahl-Hirschman Index

\begin{tabular}{|l|l|l|l|l|l|l|l|l|}
\hline A. According to deflated total assets \\
\hline 1996 & 1997 & 1998 & 1999 & 2000 & 2001 & 2002 & 2003 & 2004 \\
\hline 1623.6 & 1601.5 & 1628.5 & 1414.8 & 1636.7 & 1593.6 & 1701.9 & 1480.1 & 1400.7 \\
\hline B. According to deflated total assets plus off balance sheet items \\
\hline 1996 & 1997 & 1998 & 1999 & 2000 & 2001 & 2002 & 2003 & 2004 \\
\hline 1644.3 & 1610.7 & 1618.2 & 1482.2 & 1767.9 & 1798.5 & 1912.8 & 1726.7 & 1693.1 \\
\hline
\end{tabular}


Table 4. Profitability Ratios

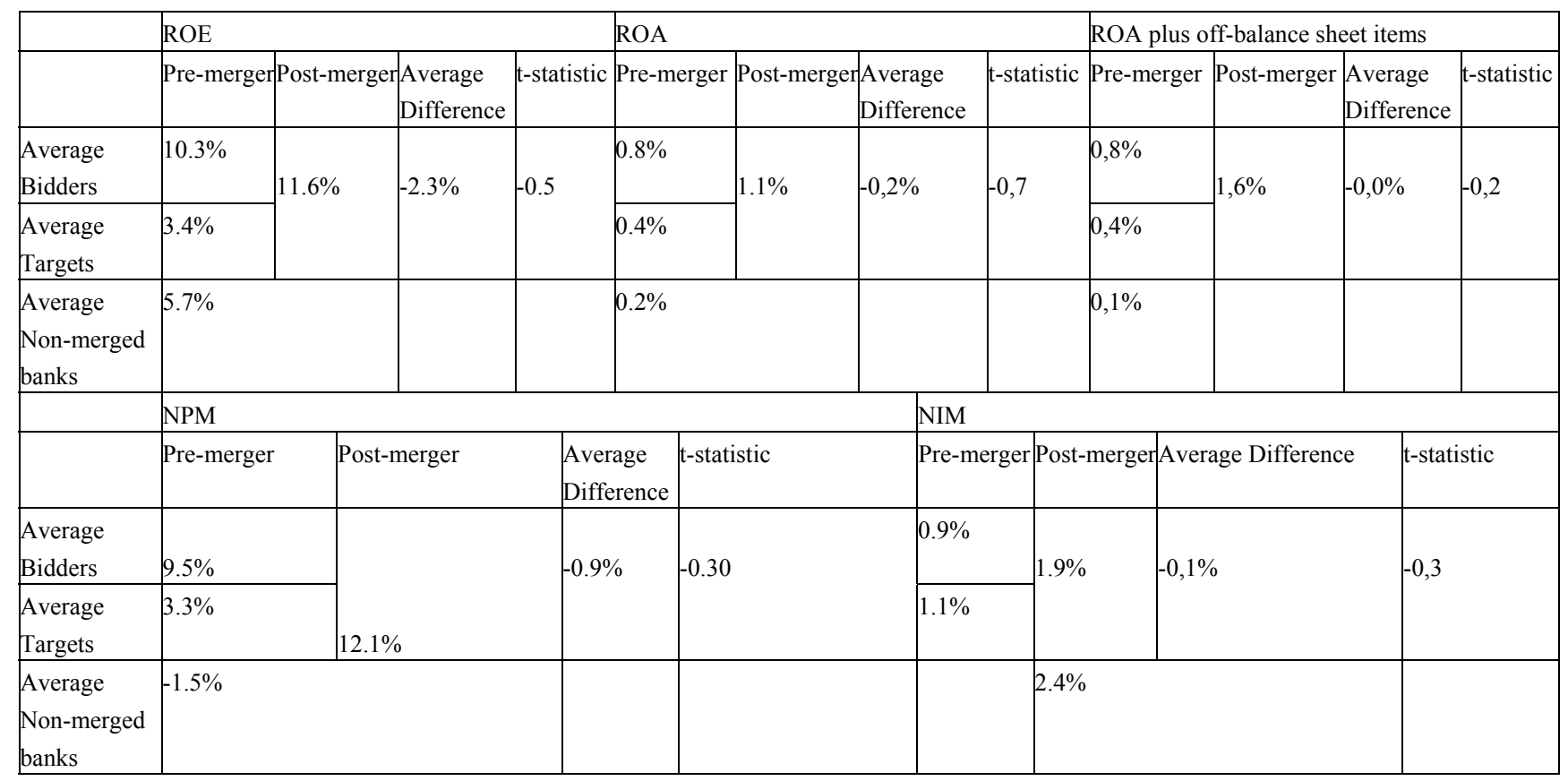

Table 5. Productivity Ratios

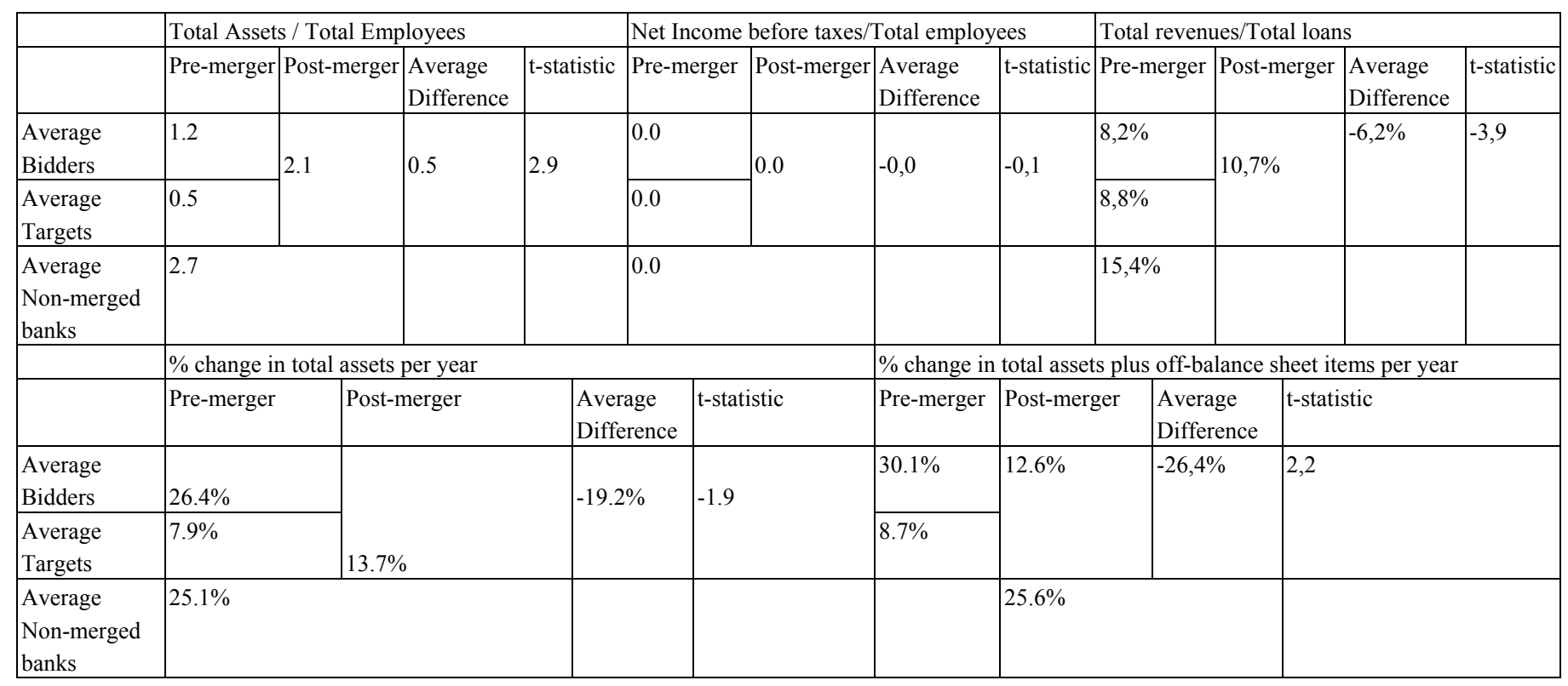


Table 6. Operating Ratios

\begin{tabular}{|c|c|c|c|c|c|c|c|c|c|c|c|c|}
\hline & \multicolumn{4}{|c|}{ Total Operating Efficiency } & \multicolumn{4}{|c|}{$\begin{array}{l}\text { Total revenues/Personnel and management } \\
\text { expenses }\end{array}$} & \multicolumn{4}{|c|}{$\begin{array}{l}\text { Total expenses/ Personnel and management } \\
\text { expenses }\end{array}$} \\
\hline & $\begin{array}{l}\text { Pre-merg } \\
\text { er }\end{array}$ & $\begin{array}{l}\text { Post-mer } \\
\text { ger }\end{array}$ & $\begin{array}{l}\text { Average } \\
\text { Difference }\end{array}$ & $\begin{array}{l}\text { t-statisti } \\
\text { c }\end{array}$ & $\begin{array}{l}\text { Pre-merg } \\
\text { er }\end{array}$ & $\begin{array}{l}\text { Post-mer } \\
\text { ger }\end{array}$ & $\begin{array}{l}\text { Average } \\
\text { Difference }\end{array}$ & t-statistic & $\begin{array}{l}\text { Pre-merg } \\
\text { er }\end{array}$ & $\begin{array}{l}\text { Post-mer } \\
\text { ger }\end{array}$ & \begin{tabular}{|l} 
Average \\
Difference
\end{tabular} & t-statistic \\
\hline $\begin{array}{l}\text { Average } \\
\text { Bidders }\end{array}$ & $50.2 \%$ & \multirow[t]{2}{*}{$63.1 \%$} & \multirow[t]{2}{*}{$-17.4 \%$} & \multirow[t]{2}{*}{-2.2} & $235.3 \%$ & \multirow[t]{2}{*}{$299.9 \%$} & \multirow[t]{2}{*}{$-76.9 \%$} & \multirow[t]{2}{*}{-2.2} & $198.2 \%$ & \multirow[t]{2}{*}{$239.6 \%$} & \multirow[t]{2}{*}{$-76,8 \%$} & \multirow[t]{2}{*}{$-2,9$} \\
\hline Average Targets & $30.8 \%$ & & & & $145.4 \%$ & & & & $122.2 \%$ & & & \\
\hline \multirow[t]{3}{*}{$\begin{array}{l}\text { Average } \\
\text { Non-merged } \\
\text { banks }\end{array}$} & \multicolumn{2}{|l|}{$68.8 \%$} & & & \multicolumn{2}{|l|}{$494.3 \%$} & & & $329.2 \%$ & & & \\
\hline & \multicolumn{4}{|c|}{ Total expenses / Total assets } & \multicolumn{4}{|c|}{ Total expenses from interest paid/Total assets } & \multicolumn{4}{|c|}{$\begin{array}{l}\text { Total expenses (except interest paid)/Tota } \\
\text { assets }\end{array}$} \\
\hline & \begin{tabular}{|l|} 
Pre-merg \\
er
\end{tabular} & $\begin{array}{l}\text { Post-mer } \\
\text { ger }\end{array}$ & $\begin{array}{l}\text { Average } \\
\text { Difference }\end{array}$ & $\begin{array}{l}\text { t-statisti } \\
\text { c }\end{array}$ & $\begin{array}{l}\text { Pre-merg } \\
\text { er }\end{array}$ & $\begin{array}{l}\text { Post-mer } \\
\text { ger }\end{array}$ & \begin{tabular}{|l} 
Average \\
Difference
\end{tabular} & t-statistic & $\begin{array}{l}\text { Pre-merg } \\
\text { er }\end{array}$ & $\begin{array}{l}\text { Post-mer } \\
\text { ger }\end{array}$ & \begin{tabular}{|l} 
Average \\
Difference
\end{tabular} & t-statistic \\
\hline $\begin{array}{l}\text { Average } \\
\text { Bidders }\end{array}$ & $4.5 \%$ & \multirow[t]{2}{*}{$5.5 \%$} & \multirow[t]{2}{*}{$-2.5 \%$} & \multirow[t]{2}{*}{-5.9} & $3.1 \%$ & \multirow[t]{2}{*}{$3.3 \%$} & \multirow[t]{2}{*}{$-1.9 \%$} & \multirow[t]{2}{*}{-6.2} & $1.4 \%$ & \multirow[t]{2}{*}{$2.2 \%$} & \multirow[t]{2}{*}{$-0,6 \%$} & \multirow[t]{2}{*}{$-2,5$} \\
\hline Average Targets & $3.5 \%$ & & & & $2.2 \%$ & & & & $1.3 \%$ & & & \\
\hline \begin{tabular}{l|} 
Average \\
Non-merged \\
banks
\end{tabular} & $5.5 \%$ & & & & $2.9 \%$ & & & & $2.6 \%$ & & & \\
\hline
\end{tabular}

Table 7. Liquidity Ratios

\begin{tabular}{|c|c|c|c|c|c|c|c|c|c|c|c|c|}
\hline & $\begin{array}{l}\text { Total loans } \\
\text { deposits }\end{array}$ & s (except & loans to bank & nks)/Total & $\begin{array}{l}\text { Total loans } \\
\text { assets }\end{array}$ & Is (except loa & ans to ban & nks)/Total & Cash plus re & reserves plus s & securities/T & Total assets \\
\hline & Pre-merger & Post-merg & $\begin{array}{l}\text { erAverage } \\
\text { Difference }\end{array}$ & t-statistic & Pre-merger & Post-merger & $\begin{array}{l}\text { Average } \\
\text { Difference }\end{array}$ & $e^{t \text {-statistic }}$ & Pre-merger & Post-merger & $\begin{array}{l}\text { Average } \\
\text { Difference }\end{array}$ & t-statistic \\
\hline $\begin{array}{l}\text { Average } \\
\text { Bidders }\end{array}$ & $19.8 \%$ & $44.5 \%$ & $8.7 \%$ & 1.6 & $16.9 \%$ & $38.6 \%$ & 7.4\% & 1.9 & $19,4 \%$ & $24,3 \%$ & $-5,6 \%$ & $-2,3$ \\
\hline $\begin{array}{l}\text { Average } \\
\text { Targets }\end{array}$ & $15.387 \%$ & & & & $13.8 \%$ & & & & $11,2 \%$ & & & \\
\hline $\begin{array}{l}\text { Average } \\
\text { Non-merged } \\
\text { banks }\end{array}$ & $51.7 \%$ & & & & $40.8 \%$ & & & & $23.5 \%$ & & & \\
\hline
\end{tabular}

Table 8. Solvency Ratio

\begin{tabular}{|l|l|l|l|l|}
\hline & \multicolumn{4}{|l|}{ Total equity/Total assets } \\
\hline & Pre-merger & Post-merger & Average Difference & t-statistic \\
\hline Average Bidders & 0.05 & 0.07 & -0.00 & $-0,60$ \\
\cline { 1 - 2 } Average Targets & 0.02 & & & \\
\cline { 1 - 3 } Average Non-merged banks & 0.11 & & \\
\hline
\end{tabular}

